\title{
PHILOLOGY
}

\section{PROBLEMATYKA OBCEGO W LITERATURZE DLA DZIECI UKRAIŃSKICH PISARZY W AUSTRALII}

\author{
Maryna Vardanian, doktor nauk filologicznych, docent \\ Ukraina, Krzywy Róg, Krzyworoski Państwowy Uniwersytet Pedagogiczny
}

DOI: https://doi.org/ 10.31435/rsglobal_ws/30112018/6239

\section{ARTICLE INFO}

Received: 15 September 2018

Accepted: 17 November 2018

Published: 30 November 2018

\section{KEYWORDS}

Children's literature,

Ukrainian Diaspora,

Dmytro Chub,

the Other.

\section{ABSTRACT}

The article deals with the writings by Dmytro Chub, who is one of the prominent representatives of the Australian Diaspora branch in the children's literature. The issues of the Other in his writings are defined as an uninhabited space, which emigrant develops. Australia is defined in author's writings as "new acquired motherland".

Citation: Maryna Vardanian. (2018) Problematyka Obcego w Literaturze dla Dzieci Ukraińskich Pisarzy w Australii. World Science. 11(39). doi: 10.31435/rsglobal_ws/30112018/6239

Copyright: (C) 2018 Maryna Vardanian. This is an open-access article distributed under the terms of the Creative Commons Attribution License (CC BY). The use, distribution or reproduction in other forums is permitted, provided the original author(s) or licensor are credited and that the original publication in this journal is cited, in accordance with accepted academic practice. No use, distribution or reproduction is permitted which does not comply with these terms.

Wprowadzenie. Australijski oddział ukraińskiej diaspory nie był tak rozległy jak, powiedzmy, w Kanadzie i Stanach Zjednoczonych, gdzie osiedliła się zdecydowana większość pisarzy, którzy pisali dla dzieci i młodzieży. Wszyscy jednak aktywnie współpracowali poprzez działania literackie, wydawnicze i edukacyjne, świadcząc o jedności w promowaniu tożsamości kulturowej Ukraińców oraz $\mathrm{w}$ poglądach na temat relacji $\mathrm{z}$ innymi społecznościami o innych doświadczeniach.

Znakomitym przykładem narodowego życia Ukraińców w Australii jest Dmytro Czub, szef australijskiego oddziału Stowarzyszenia Literatury Dziecięcej imienia L. Glibowa, który ukorzenił sie na piątym kontynencie, rozwijając tutaj literature dla dzieci i młodzieży jako poetyckim słowem tak i ofiarną pracą. Zrozumieniu problematyki twórczości dla dzieci Dmytra Chuby, która nie została przedmiotem gruntownego badania krytyków literackich poświęcony temat niniejszego artykułu.

Rezultaty. Zwrócenie się do napisania utworów dla dzieci i młodzieży nie było przypadkowym dla Dmytra Chuby (D. Nytczenka). Było na to co najmniej kilka powodów, rozważał I. Dziuba

Po pierwsze, zaczął pisać dla dzieci w końcu lat 20; po drugie, «kierował nim patriotyczny pomysł: dać ukraińskim dzieciom książki, które pomagały by im ujrzeć interesujące w nowym świecie i zrozumieć jego, trzymając się ukraińskiego słowa» (Dziuba, 2013: 319). Postawił przed sobą takie zadanie i jako szef australijskiego oddziału Stowarzyszenia Pracowników Literatury Dziecięcej, własnym przykładem próbował wzbogacić zawartość i gatunek ukraińskiej literatury. Jego twórczość jest reprezentowana $\mathrm{w}$ prozie (eseje, opowiadania) $\mathrm{i}$ poezji, przepojoną $\mathrm{z}$ jednej strony wspomnieniami, z drugiej - wrażeniami z krajów egzotycznych. Niniejsze osobliwości stylu artysty wykazują książki «Stało się to w Australii» (1953), «Na wężowej wyspie» (1953, 1958), «Szlakami przygód» (1975), «Śladami Mikłucho-Makłaja» (1993).

Po drugie, Dmytro Czub popularyzował ukraińską książkę na emigracji poprzez działalność redakcyjną, wydawniczą i kulturalną. Był przewodniczącym Klubu Literacko-Artystycznego imienia 
W. Symonenka oraz przez długi czas redaktorem almanachu «Nowy Horyzont» (założonych w roku 1954), poświęconego literaturze, sztuce i życiu kulturalnym Ukraińców Australii. W almanachu, wraz z krytycznymi rozważaniami, były publikowane dzieła Ukraińców Australii..

W tym samym czasie, w założonym przez niego wydawnictwie «Jaskółka» odrębnymi publikacjami oraz w zbiorach wydrukowane zostały księgi. Łącznie, od początku publikacji pierwszej ukraińskiej księgi w roku 1951 w Australii i do roku 1995 takich wydań różnego gatunku i przeznaczenia D. Nytczenko naliczył ponad dwieście, (Nytczenko, 1998: 659). Właśnie literatura dziecięca Ukraińców w Australii reprezentowana jest przez P.Wakulenkȩ. G.Wysznewego, L.Gajewską-Denes, N. Gruszeckiego, M. Dejkę, B. Kowalenkę, Z. Kohuta, J. Masliaka, I. Nariżnę, W. Onufrijenkẹ, Bożenę Sibo, Halyny Chornobytską, Dmytra Czuba, K. Foltca i in., wśród których młodsze pokolenie Ukraińców australijskich. Ich twórczość jest reprezentowana przez eseje, opowiadania, legendy, wierse, bajki, w których urzeczywistniają się problemy wartości kulturowych i moralnych, prawa do tożsamości i różnicy.

Po trzecie, Dmytro Czub należał do tych liderów diaspory ukraińskiej, którzy aktywnie wyznawali ideę ciągłości pokoleń. Jej praktyczną realizacją stała wychowana przez niego generacja młodych pisarzy, krytyków i tłumaczy, czym wykazał, że idea Stowarzyszenia istnieje nie tylko na papierze. Jego sprawa kontynuowana córkami O. Tkacz (Lesya Bohuslawec) i H. Koszarską, wnukiem J. Tkaczem i innymi młodymi pisarzami i naukowcami. Niewątpliwym temu dowodem jest wspomniany już «Nowy horyzont», w dwunastym numerze którego za rok 2005 zostały kontynuowane tradycję almanachu.

W swoich wspomnieniach «Pod słońcem Australii» o ówczesnych nastrojach Ukraińców którzy przybyli do nowej osady w Australii w 1949 roku, D. Nytczenko pisze:«... przed każdym pojawiły się również inne pytania i wątpliwości: jaki los spotkał tutaj nasze dzieci? Czy nie zgubią się one wśród obcego morza, tracąc swój język, kulturę i tradycję - wszystko najświętsze, co przywiozły ze sobą w swoich sercach i głowach» (Nytczenko, 1994: 8). Zachowanie tożsamości kulturowej Ukraińców i jej odzwierciedlenie w nowej generacji stało się kolejnym wyzwaniem dla D. Nytczenki, który również należał do aktywnych organizatorów szkolnictwa w Australii. W twórczości dla dzieci i młodzieży odzwierciedliło się to w potrzebie poznania obu krajów - Australii i Ukrainy.

Właściwie to połączenie oryginalnych wrażeń $\mathrm{z}$ egzotycznego kraju z nostalgią o ziemi macierzyńskiej, Ukrainie, jest wyróżniającą cechą dzieł australijskich pisarzy diasporyjnych. A. Mychajlenko podkreślił tą dwoistość w przedmowie do książki «Blizkie głosy $\mathrm{z}$ dalekego kontynentu», rozważając drogę ukraińskiego procesu literackiego i wydawniczego w Australii. W związku z tym struktura książki podzielona jest na dwie sekcje o symbolicznych nazwach: «Serce matki» i «Jadąc na obczyznę». Zdaniem samego naukowca: «W pierwszych książkach, a zwłaszcza poetycznych, napotykamy zachwycenie naprawdę bajecznym krajem, gdzie rosną wspaniałe drzewa, żyją niezwykłe zwierzęta, gdzie wszystko imponuje i zaskakuje. Wydaje się, że pierwsze wrażenia na jakiś czas odrzucają dręczące myśli o zostawionej Ojczyźnie, nawet o swoim tegoczasowym miejscu w obcym kraju» (Mychajlenko 1993: 11).

Taka wewnętrzna sprzeczność właściwa jest także dla zbioru opowiadań, esej, wierszy Dmytra Czuby «Ścieżkami przygód». I jeśli druga część książki zatytułowana «Z ojczystego pola» obejmuje pracę związane z Ukrainą, jej obrazami i postaciami, głównie T. Szewczenki, to pierwszy rozdział «Z australijskich przygód»- jest to percepcja wrażeń od Australii, która wystąpiła przytułkiem dla wielu Ukraińców. W ten sposób pisarz odtworzył obraz Australii, przekazując nastroje ówczesnej emigracji. Na ogół są one ujawnione we wspomnieniach pisarza: «Przed nami był nowy kraj, nowi ludzie z swoją mentalnością i zupełnie innymi poglądami» (Nytczenko, 1994: 7). Dlatego Australia w utworach Dmytra Chuby jest to pogląd Ukraińca -wygnańca. Tutaj codzienny świat Ukraińców podzielony na bliski i daleki, gdzie pierwszy - ojczysta ziemia, Ukraina, drugi - cudza ziemia jako niezamieszkała przestrzeń.

W swojej zbiórce Dmytro Czub przedstawia kilka sposobów prezentacji obcego kraju: obrazy egzotycznych pejzaży; niebezpieczeństwa, które czekają na nowych przybyszy; zwyczaje rdzennej ludności Papuasów. Przede wszystkim w sposób kontrastujący została opisana przyroda nieznanej przestrzeni: las stepowy i nieprzejezdne gąszcze, nieznośny upał i chłód, króliki i różne gady, pająki, drapieżniki.

Właśnie nazwy utworów wymienionego zbioru «Gnała ich śmierć», «Przypadkowe spotkanie», «Przygoda z kangurem», «Stało się to w Australii», «Przygoda z krokodylem», «W leśnych zaroślach Australii» prezentują Australię jako ciekawy i niebezpieczny kraj, zapoznanie się z którym zaczyna się od znajomości z przyrodą. Jar Slawutycz określił zbiór następująco: «Nowe tematy, dawuny i krokodyle, kangury i innej zwierze zobaczone po raz pierwszy na piątym kontynencie swoją egzotyką wciągają czytelnika od pierwszej strony» (Slawutych, 1992: 301). 
W wizji Dmytra Czuba wizerunek Australii - to ogólny wizerunek pierwotnego świata, w którym człowiekowi i mieszkańcom fauny, takim jak papugi, kukabary, kangury, posumy, byki, boa, krokodyle bedą musiały ze sobą wspólistnieć. Więc każdy utwór zawiera jakąś przygodę w życiu nowo przybyłego: polowanie na króliki i znajomość z oposem, chronionym przez prawo australijskie («Australijski Miś») atak stada rogatego bydła («Gnała ich śmierć») lub dwumetrowej jaszczurki («Niespodziewany») lub kangura («Przygoda z kangurem»), a nawet wielkiego węża «dawuna» ( «Stało się to w Australii»).

To co jest dalekim dla obcego, ukraińskiego emigranta jest krewnym i bliskim dla autochtonów. Dla Dmytra Czuba nimi są nie te mieszkańcy Australii, którzy przybyli do niej po kolonizacji kontynentu. Wydaje się, że w tym kontekście pisarz podzielił ocenę kolonizacji kraju innego badacza, ukraińskiego emigranta w Australii T. Ljachowicza: «Australia nie ma przeszłości i dla Australijczyków takie rzeczy są niezmienne» (Ljachowicz, 1966: 50). Dlatego dla Dmytra Czuba miejscowy - to tubylec pochodzący z wysp Mikronezji, który cały czas przebywał w kolonii pewnego państwa. Autor zmienia stereotypową postaw wobec Obcego jako niebezpiecznego i wrażego dla «białego» człowieka, ponieważ opowiada nie tylko o zwyczajach, języku, historii i wartościach miejscowych aborygenów, ale również o pokojowym wspólistnieniu różnych ras. Relacje te są zaprojektowane i dla Ukraińców «Ci, którzy chodzą w chlap-chlap» i «Rozmowa z Papuasem». W taki sposób przebiegało wypełnienie nieznanej, obcej przestrzeni swoją - tą, która została utracona.

W utworach Dmytra Czuby wyróżniają się kilka etapów oswajania obcej przestrzeni związane z rekonstrukcją biografii Ukraińca-wygnanca. Pierwsza znajomość i pierwsze wrażenia mieszają się z rozczarowaniem, rozpaczą, niepokojem. Możemy to spostrzegać w jego utworze «Australijski Miś», gzie wyświetlone zostały te emocje uchodźców europejskich z Ukrainy: «A ojciec z bólem w sercu, nie wiedział jeszcze, jakie życie może przytrafić się jego dziecku w tym dalekim i obcym kraju, w którym inne drzewa i ptaki, gdzie na drodze trzeba trzymać się lewej strony, gdzie słońce chodzi z lewa, gdzie nawet żaby kumkają inaczej niż na Ukrainie» (Czub, 1975: 8). Tutaj wygnaniec traktuje się jak obcy. Ale przestrzeń Swego jest wyimaginowana, sięgając wspomnień o Ukrainie, jej toposy Zaporoże, Dniepr i Chortyca jako odwieczny symbol wolności dla Ukraińców. Niebezpieczeństwa Obcego występują tutaj jako projekcja na wszystko nieprzyjazne, co zniszczyło ojczysty kraj. Taką analogią w dziełach jest wojna i represje stalinowskie.

Inna strona wygnania - to rola nowo przybyłego: ciężka praca, zarobki, rozłąka z rodziną. Tą trudną sytuację D. Nytchenko uznawał za nieludzką postawę w swoich wspomnieniach: „Najpierw byliśmy jak raby: nasze rodziny zostały podarte na strzępy i wysłane czasem na tysiące kilometrów od siebie ..." (Nytczenko, 1994: 7). Dlatego rekompensatą wewnętrznej dewastacji stała się formacją własnego mikrokosmosu. W szczególności wypełnienie Przestrzeni Swoim w opowiadaniu "Przypadkowe spotkanie" wiąże się z psem Najdą. Jego główny bohater Wasylko, pomimo ryzyka deportacji całej rodziny, nielegalnie przywiózł jego do Australii. Występuje tutaj jako żywy symbol komunikacji z ojczyzną i wartownikiem nowego.

Procesy oswajania przestrzeni występują również w utworach zbiorki Dmytra Czuba «Ścieżkami Przygód». Ukorzenienie Ukraińców jest realizowane poprzez budowę domu. Na poziomie symbolicznym taki obraz nabiera znaczenia nowej Ojczyzny. W większych zakresach oswajanie przestrzeni związane z rozwojem gospodarstw ( $\mathrm{W}$ gęstwinę lasu australijskiego»), «Domowy kangur Hop-Нор»). A w wymiarze duchowym jest to grupa Ukraińców jako świadczenie tożsamości Ukraińców, jego poczucia wspólnoty etnicznej. Wspieranie Swego i wchłonięcie Obcego jako model współistnienia osiąga się również poprzez uczenie się języków różnych kultur ( «Nispodziewany atak»).

Podobne motywy znajdują się również w utworach innych pisarzy ukraińskich w Australii. W szczególności, horyzonty teraźniejszego Swego zostały określone w „Horyzont” Haliny Czornobyckiej „ «Ja już przyzwyczaiłam się do krajobrazu, które dzisiaj mnie otaczają, pokochałam rozłożyste, szlachetne korony drzew eukaliptusowych na tle błękitnego nieba, zauroczyłam się dziecięcą łaskawością rozkwitłej mimozy i przenikniętym oślepiającym złotym słońcem, różowy kwiat migdałowy wydaje mi się najdoskonalszym sonetem» (Czornobycka, 1954: 79). Tutaj obraz horyzontu jest symboliczny. Horyzont to nadzieja i dążenie, połączenie przeszłości z przyszłością, Ukrainy i Australii

Wyniki. W literaturze ukraińskiej diaspory w Australii, która w niniejszym artykule została przedstawiona utworem «Ścieżkami Przygód» Dmytra Czuba, obraz Australii powstaje jako niezamieszkała przestrzeń, którą opanowuje Ukrainiec-wygnaniec, oraz nowa «zdobyta ojczyzna».Wraz z rekonstrukcją biografii Ukraińca-wygnańca pisarz wizualizował nie tylko egzotykę kraju, również pokazał jej rdzennych mieszkańców, podejmując ideę współistnienia różnych kultur, narodów i grup etnicznych. 


\section{LITERATURA}

1 Dziuba, I. (2013). Na trzech kontynentach. Kijów: Wydawnictwo "KLIO".

2 Nytczenko, D. (1998). Z literacko-wydawniczego życia w Australii: eksploracja bibliograficzna. W książce: Nytczenko. D. Ukraińcy w Australii (s. 656-686). Melbourne: Związek Ukraińskich Organizacji Australii.

3 Nytczenko, D. (1994). Pod stońcem Australii. Melbourne: wydawnictwo Bajda.

4 Mychajlenko A. (red.). (1993). Bliskie głosy z dalekiego kontynentu: dzieła wspótczesnych ukraińskich pisarzy w Australii. Kijów: Wesełka.

5 Sławutych, J. (1992). Literatura ukraińska w Kanadzie. Edmonton: Sławutych

6 Ljachowycz, T. (1966). Jedziemy do Australii. Oderwane od ziemi ojczystej. W T. Ljakhowych (red.). Ukraińcy w Australii (strony 30-51). Melbourne: Towarzystwo Naukowe im. Szewczenki w Australii; Uzupełniony przez Związek Ukraińskich Organizacji Australii.

7 Czub, D. (1975). Ścieżkami przygod. Melbourne: Proswita.

8 Czornobycka, H. (1954). Horyzont Nowy horyzont, 1, 79-80. 